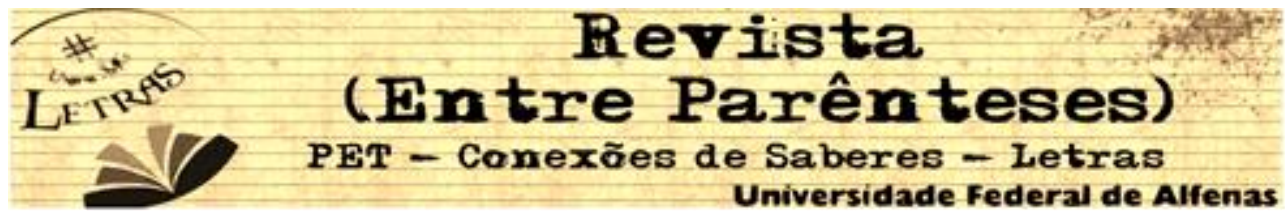

\title{
ROMANCE DO CONQUISTADOR(1991): A RECRIAÇÃO DO MITO DONJUANESCO NO NORDESTE BRASILEIRO
}

\author{
Aline Oliveira Arruda ${ }^{1}$ \\ Universidade Federal de Campina Grande \\ (alinearrudaufcg@gmail.com) \\ Isis Milreu² \\ Universidade Federal de Campina Grande \\ (imilreu@gmail.com)
}

Resumo: Don Juan é um personagem conhecido mundialmente. Seu primeiro registro na literatura foi na obra El Burlador de Sevilla y Convidado de Piedra (1630), do espanhol Tirso de Molina (1630). Nesse trabalho examinaremos as características do mito donjuanesco presentes no personagem João, protagonista de Romance do Conquistador (1991), de Lourdes Ramalho. A dramaturga, ao reescrever o mito de Don Juan, cria personagens do universo do Nordeste brasileiro que se relacionam com o mito donjuanesco. Os objetivos desse estudo são identificar e analisar as principais características do mito donjuanesco na mencionada peça de Ramalho: a sedução, a mobilidade, o disfarce e o sobrenatural. Justifica-se nosso trabalho devido à necessidade de ampliar os estudos sobre a obra da dramaturga nordestina. Entre os nossos referenciais teóricos encontram-se ANDRADE (2006), BRUNEL (1997) e OLIVEIRA (2013), dentre outros.

Palavras-chave: Romance do Conquistador; Mito donjuanesco; Literatura Brasileira Contemporânea.

\begin{abstract}
Don Juan is a character known worldwide. His first record in literature was in the book $E l$ Burlador de Sevilla y Convidado de Piedra (1630), by the Spanish Tirso de Molina (1630). In this work we will examine the characteristics of the Don Juan's myth, present in the character João, protagonist of Romance do Conquistador (1991), by Lourdes Ramalho. The playwright, rewriting the myth of Don Juan, creates characters from the universe of the Brazilian Northeast that relate to the Don Juan's myth. The objectives of this study are to identify and analyze the main characteristics of the myth of Don Juan in the Ramalho's play: seduction, mobility, disguise and supernatural. Our work is justified due to the need to expand the studies on the work of the Northeastern playwright. Names such as ANDRADE (2006), BRUNEL (1997) and OLIVEIRA (2013), among others, constitute our theoretical references.
\end{abstract}

Keywords: Romance do Conquistador; Myth of Don Juan; Contemporary Brazilian Literature.

Resumen: Don Juan es un personaje conocido en todo el mundo. Su primera aparición en la literatura fue en la obra El Burlador de Sevilla y Convidado de Piedra (1630), del español Tirso de Molina. En este trabajo examinaremos las características del mito donjuanesco presentes en el

\footnotetext{
${ }^{1}$ Graduada em Letras-Espanhol pela Universidade Federal de Campina Grande (UFCG).

${ }^{2}$ Doutora e Mestra em Letras pela Universidade Estadual Paulista (Área de Conhecimento: Literatura e Vida Social). Professora de literaturas hispânicas da Universidade Federal de Campina Grande (UFCG).
} 


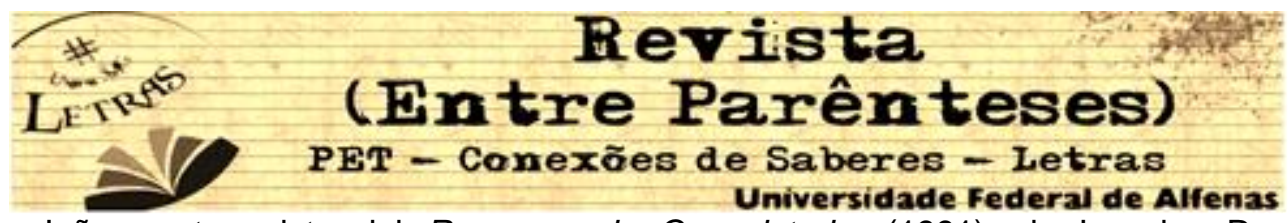

personaje João, protagonista del Romance do Conquistador (1991), de Lourdes Ramalho. La dramaturga, al reescribir el mito de Don Juan, crea personajes del universo del Nordeste brasileño, los cuales se relacionan con el mito donjuanesco. Los objetivos de este estudio son identificar y analizar las principales características del mito donjuanesco en la mencionada pieza de Ramalho: la seducción, la movilidad, el disfraz y el sobrenatural. Nuestro trabajo se justifica debido a la necesidad de ampliar los estudios sobre la obra de la dramaturga nordestina. Entre nuestros referenciales teóricos se encuentran ANDRADE (2006), BRUNEL (1997) y OLIVEIRA (2013), entre otros.

Palabras clave: Romance do Conquistador; Mito donjuanesco; Literatura Brasileña Contemporánea.

\section{INTRODUÇÃO}

Don Juan, desde que surgiu na conhecida obra de Tirso de Molina El Burlador de Sevilla y Convidado de piedra (1630), ganhou novas roupagens, uma vez que o personagem frequentou as mais diversas formas de artes. Ribeiro (1988, p.129) afirma que "Na qualidade de personagem mítica, Don Juan tem a capacidade de se reencarnar, de ressurgir a cada século com as características de um novo momento histórico [...]". A citação nos mostra que enquanto mito, ele pode estar em diversas épocas. O pesquisador acrescenta que Don Juan é um mito construído historicamente. Contudo, é importante assinalar que

Don Juan de Tirso não é inicialmente uma figura mítica. Se converterá em tal, ao se tornar independente de seu autor, da obra a que pertence originariamente, começando uma vida própria, autônoma, passando de autor em autor, de obra em obra, de uma época a outra, em um renascer e evolução contínuos ${ }^{3}$. (LORENZO, 2001, p. 107, tradução nossa).

Dessa forma, observamos que Don Juan transformou-se em um mito literário, ressurgindo em outros lugares, com novas vidas, nas mãos de diversos autores. Nesse processo, ganhou uma maior abrangência e a temática foi estudada

\footnotetext{
3 "El Don Juan de Tirso no es inicialmente una figura mítica. Se convertirá en tal al «independizarse» de su autor, de la obra a la que pertenece originariamente, comenzando una vida propia, autónoma, pasando de autor en autor, de obra en obra, de una época a otra, en un renacer y evolución continuos". (LORENZO, 2001, p.107)
} 


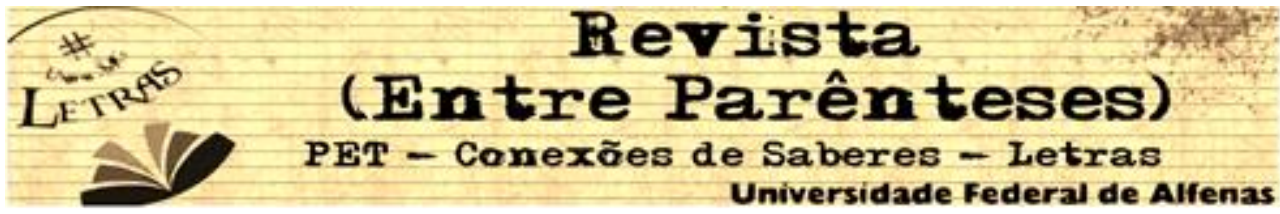

por vários pesquisadores.

Cabe frisar que o mito literário retorna em outras linguagens e em novas versões, já que representa e traz elementos que despertam o interesse humano, fazendo assim um movimento circular. Nessa perspectiva, permanecem traços e características da obra literária original, os quais podem sofrer alterações, de acordo com a época representada. Para Oliveira (2000, p. 95), "[...] o mito literário vai provocar interesse e uma continuidade, motivando em outros escritores novas versões ou adaptações do seu esquema narrativo". Constatamos que essa continuidade está presente no mito literário donjuanesco, pois ele é recriado por inúmeros autores. Assim, Don Juan aparece em distintos lugares e períodos históricos, incorporando características de um novo contexto.

Uma das obras que recriam o mito donjuanesco é a peça Romance do Conquistador (1991), da dramaturga nordestina Lourdes Ramalho. A seguir, apresentaremos, inicialmente, o contexto de criação da peça, bem como sua autora, e depois examinaremos a referida obra a fim de identificar e analisar as características do mito donjuanesco presentes nesta ficção.

\section{O CONTEXTO E A AUTORA}

No início da década de 1990, o Brasil passava por um período de instabilidade política. O país estava devastado por uma grande crise econômica. Então, o mercado editorial passa a dar maior visibilidade para as produções do país e, aos poucos, os contos e romances nacionais começam a ter notoriedade. Neste contexto, surge uma encomenda para Lourdes Ramalho dentro do Projeto de Incentivo à Dramaturgia de Cordel, desenvolvido em Campina Grande, sob a coordenação do ibero-brasileiro Moncho Rodríguez, em parceria com o Centro Cultural Pascoal Carlos Magno. Dessa forma, ela escreve o Romance do 


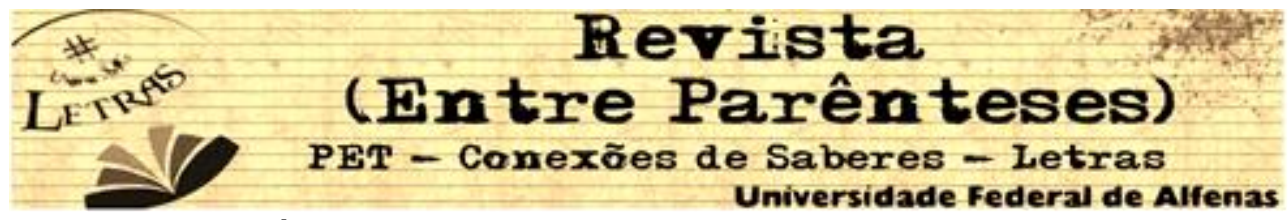

Conquistador, o qual é encenado pela primeira vez em 1991, em Pernambuco, em comemoração aos 150 anos da presença da Embaixada da Espanha no Brasil. Em 1992, a peça circulou pela Espanha por ocasião da comemoração dos 500 anos da chegada dos espanhóis à América.

Ramalho teve como desafio reescrever o mito de Don Juan em linguagem de cordel, trazendo para a cena um personagem que mesmo contendo influências espanholas, encontra-se no imaginário nordestino. Assim, a peça é construída como uma maneira de mostrar a sociedade brasileira refletida através de outra. Andrade (2006, p. 24), destaca que:

Reescrito como cordel destinado à cena, o mito renascentista, atualizado por Lourdes Ramalho à luz de dinâmicas sociais e culturais do universo popular nordestino, mistura elementos formais e estruturais do texto dramático e do texto em verso popular, resultando numa espécie híbrida, em que se alternam ação e narração.

Logo, em Romance do Conquistador (1991), a dramaturga faz uma junção de elementos característicos das literaturas nordestina e espanhola, proporcionando ao leitor uma nova versão do mito donjuanesco. A seguir, apresentaremos a autora.

Maria de Lourdes Nunes Ramalho nasceu no dia 23 de agosto de 1923, no sertão de Jardim do Seridó, Rio Grande do Norte. Professora, poeta, dramaturga e pesquisadora, a escritora vem de uma família de artistas e educadores. Em sua infância, ela conviveu com contadores de histórias de folhetos e de violeiros que fizeram nascer nela a paixão por suas raízes culturais.

Desde cedo, incentivada por familiares, Ramalho começa a escrever peças teatrais, criando personagens que foram, inicialmente, interpretados por familiares. Seu primeiro texto dramático foi escrito e encenado quando ela era ainda adolescente. Na ocasião, quis fazer uma denúncia sobre a falta de professores qualificados e os maus tratos sofridos no colégio interno que estudava no Recife, 


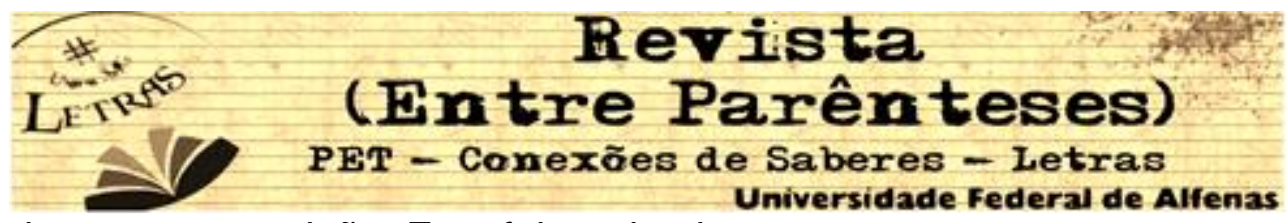

resultando em sua expulsão. Este foi o primeiro passo para que novos textos fossem criados e vários personagens fossem surgindo.

No início da década de 1950, inspirado pelo Teatro de Arena de São Paulo, surge um novo movimento na cena teatral em Pernambuco, com Hermilo Borba Filho e Ariano Suassuna, dentre outros artistas. Eles criam o Teatro Popular do Nordeste com o propósito de fortalecer a cena teatral com textos voltados para mostrar expressões características da região nordestina, bem como histórias do imagético popular. Inspirados por este processo, outros grupos começam a se formar no Nordeste e assim surge o Teatro do Estudante da Paraíba, cujo objetivo estava centrado na renovação da cena com foco na cultura popular.

Todos estes movimentos produziram uma efervescência cultural e em meados da década de 1970, a dramaturgia de Lourdes Ramalho começa a ser encenada em todo o Brasil. Dentre seus espetáculos desta época destacam-se: Fogo-Fátuo (1974), As Velhas (1975), A Feira (1976), Eleição (1977) e Os MalAmados (1977), com os quais conquista notoriedade no cenário nacional. Segundo suas declarações, a dramaturga queria reinventar o universo nordestino, sem esquecer suas heranças culturais.

Alguns estudiosos dividem a obra de Lourdes Ramalho em duas fases, denominadas de Primeiro e Segundo Ciclo. No primeiro Ciclo, a dramaturga aborda em suas produções temas como a seca, a migração, o poder político e relacionamentos inacabados, bem como questões relacionadas com o protagonismo feminino. O Segundo Ciclo inicia-se a partir da década de 1990, época em que Ramalho prioriza a ressignificação de suas raízes étnico-culturais no universo popular nordestino.

Lourdes Ramalho obteve notoriedade nacional e internacionalmente. Sua produção literária recebeu muitos prêmios. Um deles foi referente ao texto As Velhas (1975) que conseguiu o primeiro lugar no III Festival da Federação Nacional de 


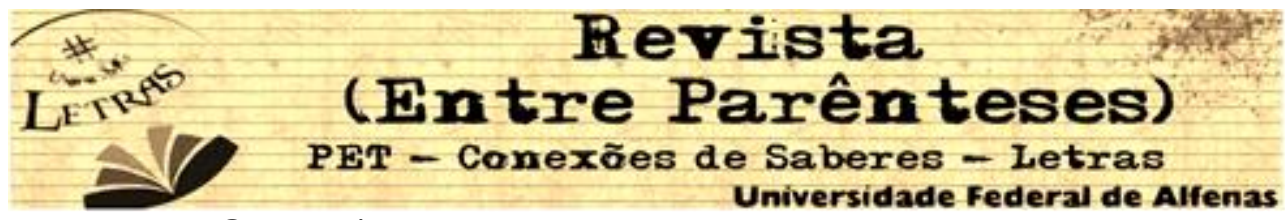

Teatro, em Ponta Grossa/PR, com destaque para Melhor Atriz e Melhor Partitura Musical. Esta obra também ganhou o prêmio de Melhor Espetáculo no XII FITEI Festival Internacional de Teatro de Expressão Ibérica em Portugal no ano de 1990, bem como premiações de Melhor Espetáculo e Melhor Figurino no V Festival Nacional de Teatro de Arte da Paraíba.

Consagrada como a dama da Dramaturgia Nordestina, Ramalho se destaca por trazer para o teatro elementos característicos de suas raízes nordestinas. Pesquisadores como Diógenes Maciel e Valéria Andrade (2011) vêm se dedicando a estudar suas obras, trazendo ao público contribuições acerca de sua dramaturgia e reeditando seus textos.

A partir da década de 1990, Ramalho prioriza o teatro em cordel em sua produção escrita teatral. Segundo Andrade e Maciel (2011, p. 19 apud LIMA; FARIA, 2006, p. 97), "[...] São chamados de teatro de cordel os espetáculos apresentados por contadores de histórias, com a função didática de divulgar os folhetos, mesmo sem a adaptação propriamente dita para a cena". Entretanto, Andrade e Maciel (2011, p. 27) ponderam que:

Para além de uma simples relação com o teatro ibérico, dito de cordel, a peça de Lourdes Ramalho [...] reelabora o folheto nordestino em chave dramática, não apenas pela utilização dos versos, mas na medida em que utiliza as sextilhas, como metrificação regular em redondilha maior, como veículo para a expressão dos diálogos ou excertos narrativos.

Dessa forma, Ramalho compõe um texto teatral independente da tradicional constituição das sextilhas, nas quais os conflitos existentes entre os personagens ultrapassam a ordem das estrofes. Assim, a construção de suas falas rompe os padrões ibérico e nordestino, já que ela inova a forma de contar em suas peças. 


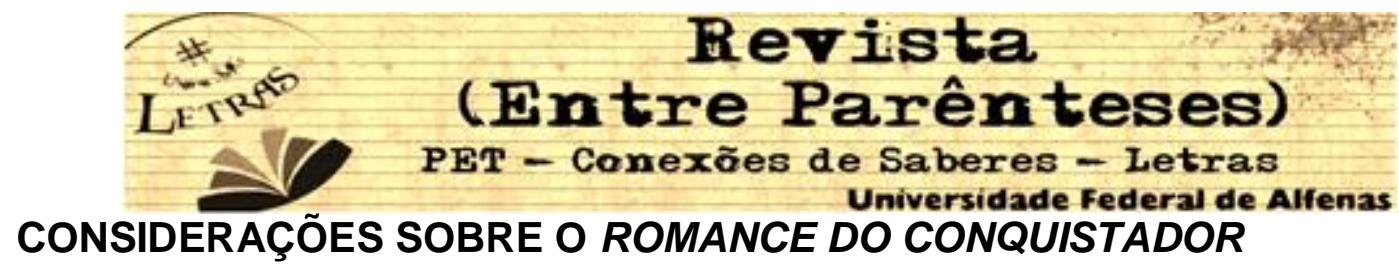

A peça Romance do Conquistador (1991) está escrita em versos e foi dividida em sete quadros, seguindo o modelo da literatura popular de cordel. Inicialmente, há um canto de abertura que ambienta o leitor ao espaço em que se desenvolverão as cenas.

No primeiro quadro, apresenta-se um narrador personagem, vendedor de cordéis, contando algumas histórias, dentre elas a de D. João Conquistador do Agreste. O quadro dois é denominado de "Barraca da Zefa". É neste ambiente que a história deste Conquistador inicia-se quando João entra em cena vendendo seu cordel a fim de matar sua fome. No quadro três, "Mesa da Zilda", João está em São Bento do Bofete, conquista Zilda e se aproveita de sua banca de vidente para atrair fregueses e ganhar dinheiro. Com gracejos e muita conversa, seduz a mulher do delegado que chega e desafia-o. João foge do conflito e parte em busca de outras aventuras para tentar sobreviver, juntamente com Zilda. Sua próxima aventura ocorre no quadro quatro que recebeu o nome de "Médico". Nesta parte, o casal chega a Santa Luzia dos Grudes, cidade devastada pelas chuvas, a qual está sem médico e tem muitos doentes. Aproveitando-se da situação, o protagonista se disfarça de médico, mas o prefeito tenta seduzi-lo e ele foge.

No quadro cinco, "Comício", João e Zilda chegam à outra cidade para buscar um meio de sobrevivência. Ali está acontecendo um comício e João finge ser um candidato e discursa chamando a atenção dos eleitores. Neste quadro percebemos uma crítica à situação do país, com a menção aos juros altos, inflação e promessas mentirosas dos políticos. A próxima cena, o quadro seis, ocorre na "Mortuária" em Santana do Monte Preto. Nesta cidade, ao ver um homem comprando o seu próprio caixão, João quer saber que herança ele vai deixar. Ele responde que deixará a perigosa Guiomar. João se apaixona mesmo sem conhecê-la, sentindo-se atraído 


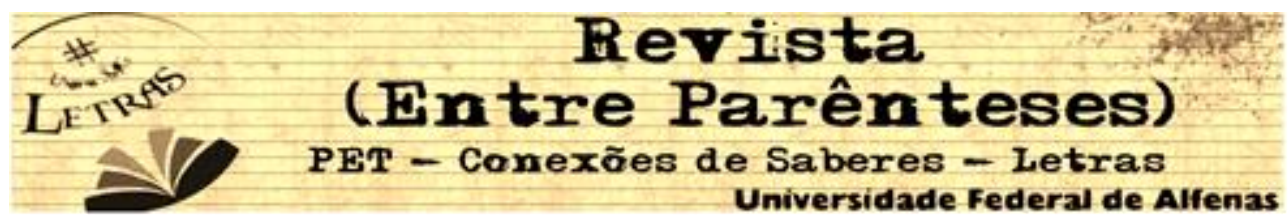

por ela. Zilda então resolve procurar alguém que a valorize e envolve-se com o dono da funerária. No último quadro, "A confissão", João está sozinho em uma igreja. Ele é seduzido por três beatas que revelam ser o diabo disfarçado de Guiomar.

A peça conta com trinta e quatro personagens. João, o protagonista, é apresentado no início do relato pelo narrador. Para escapar da fome e da seca, ele seduz e engana sempre que tem oportunidade. Vimos que João tem como companheira Zilda, uma vidente/curandeira que o acompanha na maioria das aventuras. Ele é caracterizado como conquistador, como mostra o narrador: "Vai começar a estória de D. João Conquistador [...]". (RAMALHO, 1991, p. 60). Tal como o protagonista espanhol, João leva o título de Don nesta versão brasileira, uma ironia, visto que era pobre e não um nobre. Segundo um personagem, "João só conjugou na vida os verbos mentir, brincar! Dormir, comer, dar o golpe, meter, enganar, trepar!". (RAMALHO, 2011, p. 61). Dessa forma, o que marca o protagonista é o seu poder de aproveitar-se dos outros no intuito de alimentar-se, escapar das armações cometidas e, principalmente, sobreviver. Aliás, ele sempre foge, encontrando pelo caminho novas oportunidades de sobrevivência. Para isso usa vários subterfúgios, principalmente, a sedução, tal como Don Juan.

No início do relato, o narrador/personagem conta as histórias de seus cordéis. Entre eles, está a história de João, como vemos na citação: "Chega, chega, minha gente! Venham os folhetos comprar! O romance de D. João e a perigosa Guiomar! E bata o pé na poeira que a coisa vai começar!". (RAMALHO, 2011, p. 61). Nesse episódio, a autora mostra o cordel como um produto, o qual, posteriormente, é representado, possibilitando que o leitor acompanhe João em suas aventuras.

A ação narrativa ocorre em alguns espaços do Sertão nordestino brasileiro, uma vez que a autora apresenta em seu texto elementos característicos desta região. No entanto, a dramaturga usa nomes fictícios para denominar estes lugares. Como apontamos, a história começa na feira, onde os cordéis são vendidos e a 


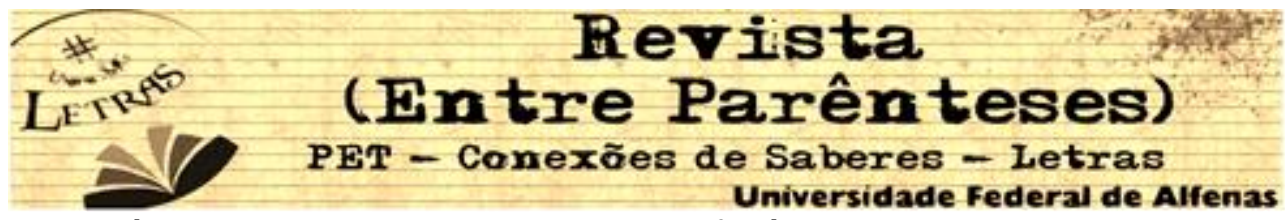

história inicial é apresentada. A barraca da Zefa é outro espaço que marca a entrada de João na peça. Em São Bento do Bofete, João conhece Zilda que o acompanha em algumas aventuras. Já em Santa Luzia dos Grudes ele se faz passar por médico e Zilda se disfarça de enfermeira. Em outra cidade que a autora não nomeia, os protagonistas estão em uma praça onde acontece um comício. Na sequência, agora em Santana de Monte Preto, a trama se desenvolve na mortuária, para logo em seguida ter seu desfecho na igreja desta cidade.

O texto está escrito no presente e segue uma linearidade, sem marcadores temporais que identifiquem com precisão o tempo da narrativa. Possivelmente, a ação narrativa acontece no segundo semestre do ano, período em que ocorrem as eleições, dado que este acontecimento aparece representado no quadro cinco.

O título da peça, Romance do Conquistador, indica o tema principal da obra, ou seja, a história de João em forma de romance. Para nosso estudo, faz-se necessário definir o termo romance. Segundo Abreu (1993, p. 214 apud ANDRADE; MACIEL, 2011, p. 24):

[...] os poetas nordestinos chamam 'romance' as brochuras de 24 páginas ou mais, que costumam abrigar narrativas ficcionais, inventadas pelos autores ou adaptados a partir de histórias tradicionais europeias ou livros eruditos. Muitas vezes, recontavamse histórias já divulgadas pela tradição oral. É interessante considerar a permanência do uso da palavra romance para designar um gênero literário que se distingue da forma romanesca desenvolvida a partir do século XVIII.

Desse modo, constituído por estrofes de seis versos, ou sextilhas, os romances narram histórias que envolvem aventura, amor, mistérios e humor em que os personagens principais e secundários são apresentados ainda na primeira estrofe. Ramalho, em sua obra, segue um modelo da literatura popular em verso, designado como romance. Contudo, romance também pode designar um gênero literário e uma relação amorosa. No que concerne ao termo conquistador, podemos 


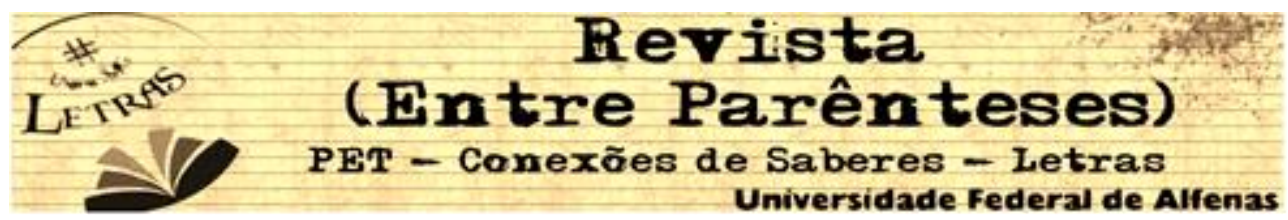

relacioná-lo à conquista dos espanhóis à América, bem como àquele que usa 0 artifício da conquista, do galanteio para atrair novos relacionamentos por meio da sedução. Assim, o título indica alguns temas que serão tratados na peça de Ramalho, inclusive, sua relação com o mito donjuanesco, conforme veremos a seguir.

\section{ASPECTOS DO MITO DONJUANESCO EM ROMANCE DO CONQUISTADOR}

O Romance do Conquistador (1991) pode ser visto como uma releitura do mito donjuanesco. Andrade (2013, p. 77), ressalta que "[...] o mito do sedutor insaciável ganha, no início da década de 90, uma nova versão, também para ser encenada, mas escrita em cordel, por uma autora brasileira". Dessa forma, o mito de Don Juan entra em cena nos palcos nordestinos, alcançando também, posteriormente, plateias europeias. A continuação, analisaremos as características principais do mito donjuanesco na mencionada peça de Lourdes Ramalho.

Vários estudiosos assinalam que a sedução é a principal marca do personagem Don Juan na peça El Burlador de Sevilla y Convidado de Piedra (1630). Assim, ele utiliza-se deste meio para enganar todos que estão ao seu redor. Ribeiro (1988, p. 25), aponta que "[...] Don Juan não seduz pelo que é, mas sim, é porque seduz". Entendemos por meio desta afirmativa que a sedução é um ponto crucial de sua identidade.

As estratégias empregadas por Don Juan na hora de seduzir consistem em provocar no outro o desejo. Ele utiliza-se principalmente da gentileza, como podemos ver em Oliveira (2013, p. 135): "Don Juan torna as mulheres felizes, prepara-se antes do gozo, despertando-Ihes o erotismo, porque não é um violador, mas um sedutor de corpo e alma”. Ele é afável, sabe agradar e manter sua fama de sedutor. 


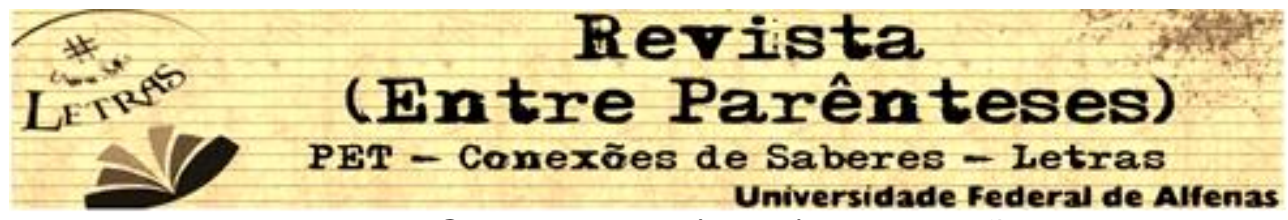

Na peça Romance do Conquistador (1991), a sedução do personagem João pode ser vista como uma estratégia de luta por sua sobrevivência. Ele aborda as pessoas que pretende enganar cortejando-as. Desse modo, João seduz Zilda e a mulher do delegado, por exemplo. Apesar de ser um grande sedutor, ele tem uma relação amorosa com a vidente Zilda que o acompanha em suas aventuras, fazendo o papel de companheira, amante e confidente, como se fosse a versão feminina de Catalinón, criado de Don Juan, na obra de Molina.

A partir do quadro quatro, os papéis começam a se inverter e João deixa de seduzir para ser seduzido pelo prefeito que diz "Doutor, mais tarde saímos, pretendo Ihe oferecer um jantar à luz de velas pra melhor lhe conhecer!" (RAMALHO, 2011, p. 84). João desconfia de suas intenções e parte para outra cidade em companhia de Zilda.

Passando por muitas aventuras, João encontra a partir do quadro seis a mais arriscada de suas seduções, pois cobiça uma herança, Guiomar, que será deixada por um suposto suicida identificado por 'homem'. O protagonista expressa o seu desejo de seduzi-la e termina abandonado pela companheira que acusa-o: "Já que não tem mais tesão, - eu, correndo, vou atrás de um bicho rijo, durão." (RAMALHO, 2011, p. 98-99). Nesse momento, Zilda decide buscar alguém que satisfaça seus desejos, indicando que ele era impotente e ela era independente. Então, João resolve procurar a perigosa Guiomar, o diabo em forma de gente, aquela que será o seu pior castigo, segundo o narrador.

Percebemos que da mesma forma que o Don Juan de Molina, o personagem João de Lourdes Ramalho, também apresenta a característica de sedutor. Conforme assinala Andrade (2006, p. 25), "[...] tão obsessivo em relação às mulheres quanto seus pares de outros tempos e outras terras, o don Juan nordestino de fins do século XX a todos se iguala por ser, portanto, antes de tudo, um sedutor itinerante". Logo, a sedução está fortemente marcada nas duas obras por meio das ações de 


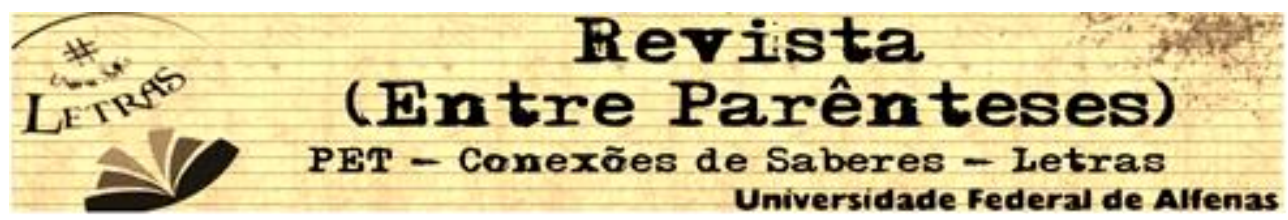

Don Juan e de João. A diferença é que Don Juan é um jovem nobre que encontra na sedução o subterfúgio para escapar de suas falcatruas e João é um vendedor de cordéis, desfavorecido que descobre na sedução a arma para garantir a sua sobrevivência. Portanto, Don Juan e João vivem em movimento, o que proporciona oportunidades de satisfazerem seus desejos de sedutores itinerantes. $O$ fato de estarem sempre mudando aponta outra marca do mito donjuanesco: a mobilidade, a qual abordaremos a seguir.

Don Juan, de Molina, é marcado por sua instabilidade. Brunel (1997) destaca que ilusoriamente ele apresenta essa característica de mudança por causa de sua facilidade em sair de um lugar para outro. Assim, sua mobilidade é uma estratégia para escapar de suas armações. Em cada lugar que o personagem se encontra, há novos enganos. Na obra do autor espanhol, essa mudança de percurso acontece de forma cíclica, uma vez que Don Juan vai, mas sempre volta para o seu lugar de origem até o seu encontro final com a morte.

João também percorre vários caminhos em busca de seu sustento e para isso utiliza-se da sedução para sobreviver. Ele "[...] tenta encontrar um jeito de se virar, de escapar! Vive pra cima e pra baixo sem saber onde parar". (RAMALHO, 1991, p. 67). Pelos caminhos percorridos pelo personagem, são retratados aspectos da sociedade e do ambiente em que ele vive no Sertão nordestino.

A mobilidade de Don Juan e João é sintetizada por Andrade (2006, p. 25):

Don Juan Tenório, burlador de Sevilla, sai de Nápoles - do palácio do Rei - para Sevilla, passando por Tarragona e seguindo, de Sevilla para a aldeia de Dos Hermanas, na Andaluzia, de onde retorna, mais uma vez a sua cidade. Já o nosso burlador, João do Agreste, sai da baixa da Égua - de uma feira - passa por São Bento do Bofete, de onde sai e, depois de atravessar muita lama, acaba chegando em Santa Luzia dos Grudes, daí passando por Barra Funda, até encontrar Santana do Monte Preto.

Dessa forma, os dois personagens se assemelham quanto à mobilidade. 


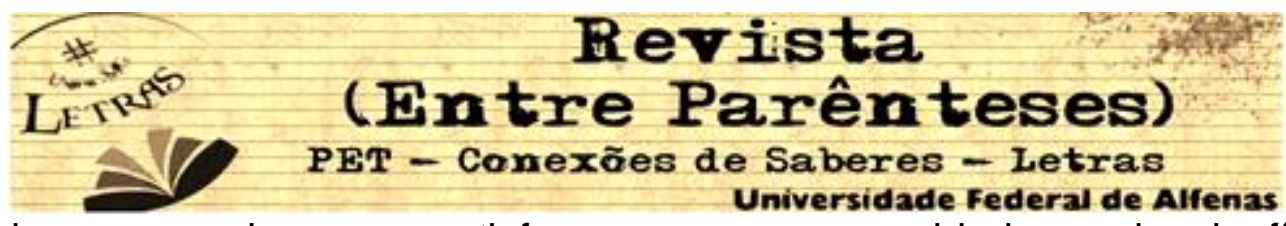

Ambos buscavam algo para satisfazerem suas necessidades, seja ela física ou material. Percorrendo caminhos em busca de sua própria realização, descobrem outras partes do mundo, conhecem pessoas e encontram novas formas de enganar. Eles não se preocupam com o futuro, porque o acaso se encarregará de mostrar em qual lugar será a nova pousada e a nova aventura. Nestes caminhos que os protagonistas percorrem para fugir, os dois utilizam disfarces. Brunel (1997, p. 256), afirma que "Don Juan cria a ilusão de mudança, ainda, pela máscara, que ele gosta de usar. É o homem do disfarce". Esta é outra característica do mito donjuanesco, como veremos a continuação.

$\mathrm{Na}$ obra de Molina, Don Juan aproveita-se de acessórios cênicos para dissimular-se e assim manter em segredo $o$ ato da conquista. $O$ autor inicia a peça com uma nota que diz: "Sai Don Juan Tenório mascarado e Isabela, a duquesa. Os dois conversam baixinho."” (MOLINA, 1978, p. 47, tradução nossa). Assim, ele já começa sua atuação disfarçado para enganar Isabela. É por meio deste artifício que o personagem de Molina seduz as duas mulheres nobres da peça, Isabela e Dona Ana, fazendo-se passar, respectivamente, pelo Duque Octávio e por la Mota. Dessa maneira, ele simula ser outro para poder chegar ao seu objetivo que é confundir e seduzir as mulheres citadas. O próprio marquês de la Mota, oferece sua capa para Don Juan dizendo: "Vamos, e coloque minha capa, para que tenha êxito." 5 (MOLINA, 1978 , p. 112, tradução nossa). No encontro com Dona Ana, o marquês foi tão enganado quanto ela. Já nos outros encontros que ocorrem na peça de Molina, com Tisbea e Aminta, Don Juan não usa acessórios como recurso de sedução. Porém, utiliza juras de amor e propostas de casamento, as quais podem ser consideradas como um disfarce linguístico ou até mesmo uma encenação, pois ele não cumprirá o que foi prometido.

\footnotetext{
4 "Sale Don Juan Tenorio, embozado y Isabela, la duquesa. Los dos hablan muy quedo." (MOLINA, 1978, p. 47).

5 "Vamos, y poneos mi capa, para que mejor lo deis." (MOLINA, 1978, p.112).
} 


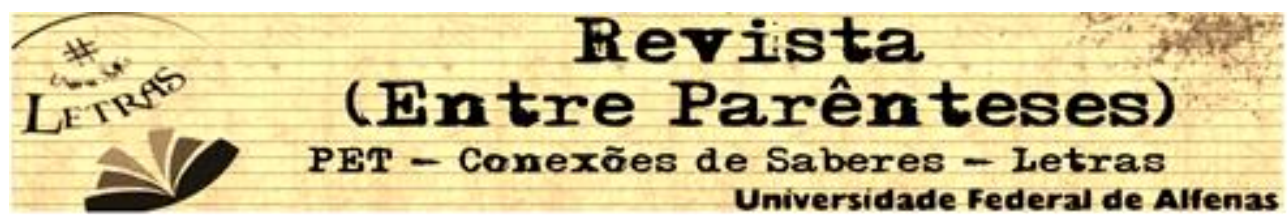

Em Romance do Conquistador (1991), o disfarce está presente na maior parte do enredo. Ao longo da história, João vai ganhando novos nomes, como macho cabra da peste, homem sexo de ferro, D. João Conquistador do Agreste, D. João, o aventureiro, João, conquistador de araque, denominações que mascaram a sua identidade, mas não escondem sua personalidade, dado que nos remetem à arte de sedução, ao sexo e ao disfarce.

$\mathrm{Na}$ peça de Ramalho, João apresentou distintas facetas. Uma delas foi o mago da sorte, um dos primeiros disfarces que ele arrumou para enganar as pessoas e assim conseguir dinheiro para poder alimentar-se. Na companhia de Zilda, que também se disfarça, na cidade de Santa Luzia dos Grudes, João viu na profissão de médico um meio de conseguir ter uma vida melhor. Ao chegar à cidade ele vê uma movimentação na praça, escuta as conversas e resolve se aproveitar da situação, disfarçando-se de médico e Zilda de enfermeira. Porém, por não satisfazer os desejos do prefeito, eles fugiram para outra cidade. Em uma praça, João aproveita a oportunidade de um comício para se candidatar a prefeito enquanto sua companheira assume o papel de primeira dama. Por último, João se disfarça de padre e Zilda de coroinha. Em suma, em cada local eles usam um novo disfarce para livrar-se da fome e tentar uma vida melhor.

Diferentemente de Don Juan que buscava por meio de seus disfarces atrair as mulheres, João tenta garantir a sua própria subsistência disfarçando-se. Assim, ele usa vários artifícios para sobreviver em meio à seca e à pobreza, encontrando no disfarce uma oportunidade para garantir o seu sustento.

A quarta característica do mito donjuanesco é o sobrenatural. Este elemento está presente desde o título da obra de Molina e faz parte de seu desfecho. Don Juan desafia a estátua de pedra do Comendador que está enterrado em uma igreja dizendo: "Esta noite espero vocês para jantar nos meus aposentos. Ali realizaremos o desafio, se a vingança te agrada; apesar de que mal poderemos brigar se sua 


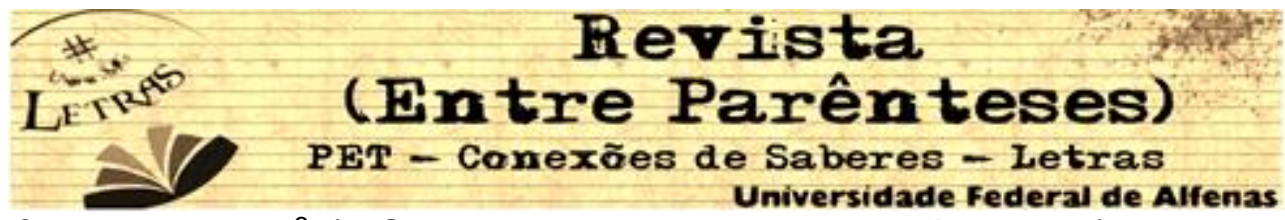

espada for de pedra." 6 (MOLINA, 1978, p. 142, tradução nossa). Por meio desta provocação surge o sobrenatural na peça. A estátua aceita o convite de Don Juan que, posteriormente, retribui o convite. Neste momento, o enganador passa a ser enganado pela estátua do Comendador, pois ao aceitar jantar com a estátua do Comendador ignora que este será o seu último momento de vida. Após recebê-lo em sua sepultura, ao terminar a refeição, aperta-lhe a mão e ele morre. Cabe frisar que a estátua de pedra castiga Don Juan não somente pelas mulheres enganadas, dentre elas a filha do Comendador, mas por ter desafiado as normas da sociedade.

No último quadro de Romance do Conquistador o desfecho ocorre na igreja. Por conseguinte, João é atraído pelo desejo de conquistar a tão desejada Guiomar. No entanto, ao entrar na igreja, sonhará com várias mulheres dançando na sua frente e ao acordar encontra três figuras femininas. Diferentemente de Molina, para finalizar a peça, Ramalho traz para a cena não uma estátua de pedra, mas três beatas: Inocência, Decência e Previdência. Elas envolvem o protagonista em um jogo da sedução, mas logo revelam que são a diabólica Guiomar. Dessa forma, avisam para João que "[...] Estás nas mãos do Perneta vestido de Guiomar! O Fute, o Cão, o Capeta vieram te levar!" (RAMALHO, 2011, p. 107). Então, a própria encarnação do diabo em forma de gente veio para levá-lo ao inferno. Por sua vez, João ainda tentou enganá-las, porém, a perigosa Guiomar ludibriou-o. Ironicamente, ele sobreviveu às dificuldades do Sertão, entre elas a seca e a miséria, mas no entanto, envolvido pelo desejo ardente oriundo dos encantos da Guiomar, não conseguiu sobreviver, pois sua paixão foi mais forte. Nesse sentido, o sedutor tornase seduzido e o mito donjuanesco é problematizado, dado que o protagonista é humanizado quando se apaixona.

\footnotetext{
6 "Aquesta noche a cenar os aguardo en mi posada. Allí el desafío haremos, si la venganza os agrada; aunque mal reñir podremos si es de piedra vuestra espada." (MOLINA, 1978, p. 142).
} 


\section{Revista \\ LETR (Entre Parênteses) \\ PET - Conexões de Saberes - Letras \\ Universidade Federal de Alfenas}

CONSIDERAÇÕES FINAIS

Acreditamos que a peça de Lourdes Ramalho, mesmo contendo características diferentes da obra escrita por Tirso de Molina, pode ser considerada uma versão de Don Juan, devido as marcas de seu protagonista. Nessa ótica, podemos afirmar que a referida ficção é uma reescrita do mito donjuanesco, a qual foi encomendada para as comemorações dos 150 anos da Embaixada da Espanha no Brasil. Em sua peça, a autora inseriu elementos típicos da região nordestina, sem abandonar os principais traços de Don Juan de Molina, uma vez que a sedução, sua maior marca, se manteve em sua obra.

Ao analisarmos as características do protagonista de Romance do Conquistador, notamos que ele cumpre seu papel como um personagem donjuanesco, pois além da sedução, estão presentes em sua caracterização três de seus elementos principais: a mobilidade, o disfarce e o sobrenatural. João, tal como Don Juan, seduz como uma marca de personalidade, mesmo que seduza, muitas vezes, para sobreviver. Personagens itinerantes, os protagonistas de Molina e Ramalho, não param por muito tempo em um lugar. Ao contrário, eles estão sempre em movimento, escapando das armações que cometem até encontrar a figura da morte representada, respectivamente, pela estátua do Comendador e por Guiomar. Os dois também usam disfarces, apesar das finalidades distintas. Don Juan utiliza-o para seduzir e enganar Isabela e Ana. Por sua vez, João disfarça-se para garantir sua sobrevivência, fingindo ser médico, candidato político e padre. Verificamos a presença do sobrenatural nas duas obras e constatamos que a estátua de pedra e a presença feminina por meio da figura das três beatas são fundamentais para o desfecho do relato.

A versão de Lourdes Ramalho da obra teatral El Burlador de Sevilla y Convidado de Piedra (1630), de Tirso de Molina, apresenta particularidades da 


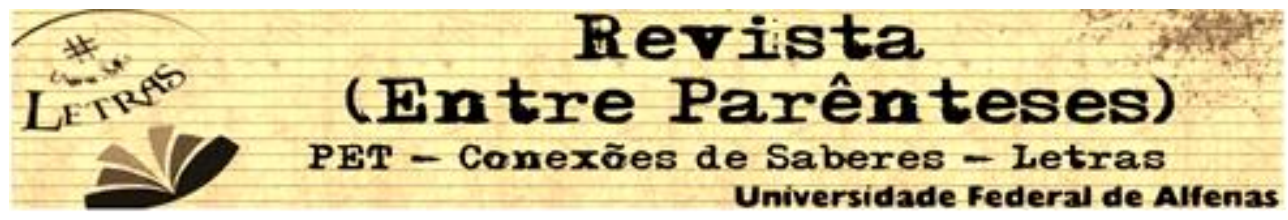

região do Nordeste brasileiro, trazendo seus elementos peculiares. Um exemplo é a linguagem utilizada pelas personagens, como podemos constatar nesta citação: "Que bichotinha atrevida! Não passa de uma bisquara!”. (RAMALHO, 2011, p.73). A autora também aborda tópicos típicos do universo nordestino, tais como a seca, a feira, as comidas, os cordéis e os animais, entre outros, além de situar a ação narrativa em espaços do sertão do Nordeste.

A partir de nossa análise consideramos que mesmo com algumas semelhanças Don Juan de Molina e João de Lourdes Ramalho apresentam também várias diferenças, dado que João é desfavorecido socialmente e seu espaço é marcado pelo desprestígio social, enquanto Don Juan é um jovem nobre, filho do conselheiro do Rei de Castela, ocupando um lugar de destaque na corte. Também é importante assinalar que João se apaixona por Guiomar, enquanto Don Juan, em suas quatro seduções, não demonstra nenhum sentimento. Percebemos, assim, que o personagem de Ramalho humaniza-se ao apaixonar-se. Outra diferença que merece destaque consiste nos "enganadores", pois Don Juan foi ludibriado por uma estátua de pedra e João pela figura das três beatas. $\mathrm{Na}$ verdade, elas eram Guiomar, a encarnação do diabo, a qual o seduziu e ocasionou sua morte. Apesar de muitos cordéis relacionarem a mulher com a figura do diabo, nesta peça podemos interpretar Guiomar como um instrumento de vingança. Assim, ela vence o conquistador com suas próprias armas.

Em suma, as duas narrativas analisadas nesse estudo retratam a sociedade de sua época, dado que a peça de Ramalho é uma recriação e, portanto, modifica o contexto da obra de Molina, além de fazer diversas adaptações. Cabe frisar que Don Juan tornou-se um personagem mundialmente conhecido ao mesmo tempo em que adquiriu algumas marcas que o identificam em outros períodos. Isso foi comprovado em nosso trabalho, no qual apontamos que Romance do Conquistador pode ser visto como uma retomada do mito donjuanesco. 


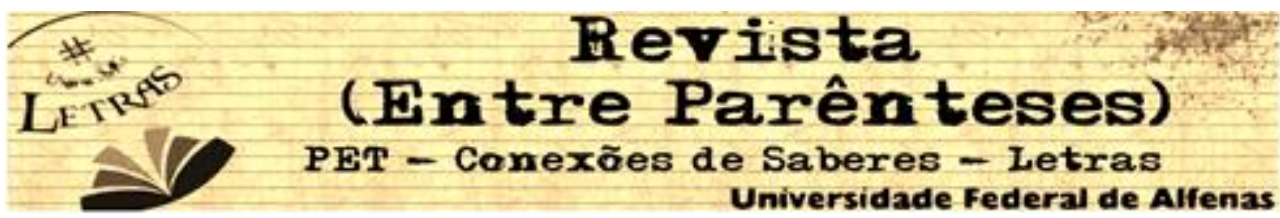

\section{REFERÊNCIAS}

ANDRADE, V. Nosso nome é Guiomar ou Lourdes Ramalho e a reinvenção de Don Juan. João Pessoa: Graphos, 2006. Disponível em: <periodicos.ufpb.br/ojs/index.php/graphos/article/view/9306/4987> Acesso em: 15 set. 2015.

ANDRADE, V; MACIEL, D. Teatro [quase completo] de Lourdes Ramalho. Vol. 01. Teatro de Cordel. Maceió: EDUFAL, 2011.

BRUNEL, P. (Org.). Dicionário de Mitos Literários. Rio de Janeiro: José Olympio, 1997.

LORENZO, M. El Mito de Don Juan en la Literatura Belga: Charles Bertín y Suzanne Lilar frente a Tirso de Molina. Anuario de Estudios Filológicos, V. 24, p. 107 - 122, 2001. Disponivel em: < https://dialnet.unirioja.es/servlet/articulo?codigo=59009> Acesso em: 17 jul. 2015.

MOLINA, T. El Burlador de Sevilla y Convidado de Piedra. Salamanca: Ed. Almar, 1978.

OLIVEIRA, E. A. V. O mito de Don Juan e sua relação com Eros e Thanatos. Vitória: Opção Editora, 2013.

RAMALHO, M. L. N. O Romance do Conquistador. In: MACIEL, D.; ANDRADE, V. Teatro [quase completo] de Lourdes Ramalho. Vol. 01. Teatro de Cordel. Maceió: EDUFAL, 2011.

RIBEIRO, R. J. A sedução e suas máscaras: ensaios sobre Don Juan. São Paulo: Companhia das Letras, 1988. 